\title{
Protein kinase activity of the insulin receptor
}

\author{
Steen GAMMELTOFT* and Emmanuel VAN OBBERGHEN $\dagger$ \\ *Department of Clinical Chemistry, Rigshospitalet, University Hospital, Blegdamsvej 9, DK-2100 Copenhagen, Denmark, and \\ †INSERM U 145, Faculté de Médecine (Pasteur), Université de Nice, Avenue de Vallombrose, F-06034 Nice Cedex, France
}

\section{Introduction}

Regulation of cellular metabolism and growth by insulin is a result of a series of events initiated by the interaction of the hormone with specific cell surface receptors. In the past, insulin receptors on a large number of cell types from different vertebrates have been characterized in detail by their functional properties: recognition of the hormone by a noncovalent binding reaction, transmembrane signalling, and activation of cell metabolism. It also became clear that receptors mediate proteolytic degradation of insulin, probably via endocytosis of the receptor-bound hormone. These results were primarily based on studies of the interaction of radioiodinated insulin with isolated cells or plasma membranes (for reviews see Kahn et al., 1981; Gammeltoft, 1984). The insulin receptor structure has been elucidated through affinity labelling of receptors by chemical cross-linking with ${ }^{\mathbf{1 2 5}}$ I-insulin, biosynthetic or cell-surface labelling of receptor subunits (for reviews see Jacobs \& Cuatrecasas, 1981 ;Czech, 1984;Van Obberghen, 1984). Recently, the complete amino-acid sequence of the human insulin receptor precursor was unravelled by application of recombinant DNA technology (Ullrich et al., 1985; Ebina et al., 1985). In spite of this progress the molecular mechanism of insulin action is still poorly comprehended regarding the events following the receptor binding and leading to the ultimate cellular responses. Possible mechanisms of intracellular signal transmission include changes in intracellular $\mathrm{Ca}^{2+}$ concentration, protein phosphorylation, release of peptide mediators, interaction with guanine nucleotide regulatory proteins and internalization of receptor-hormone complexes, but attempts to identify a second messenger in insulin action has so far been inconclusive (for reviews see Denton et al., 1981; Houslay, 1981; Houslay \& Heyworth, 1983; Czech, 1984; Bergeron et al., 1985; Cheng \& Larner, 1985).

Recently, a promising discovery was made by the demonstration that the insulin receptor is an insulinsensitive protein kinase (Kasuga et al., 1982a; Van Obberghen \& Kowalski, 1982; Avruch et al., 1982; Petruzzelli et al., 1982). This novel observation is of interest for our understanding of insulin-regulated processes, since it is now recognized that covalent phosphorylation-dephosphorylation of proteins is a mechanism whereby many cellular functions are regulated by hormones and neurotransmitters (Denton et al., 1981; Cohen, 1982; Houslay, 1981). Furthermore, protein kinases are also constituents of receptors for several polypeptide growth factors, including epidermal growth factor (EGF) (Cohen et al., 1980), platelet-derived growth factor (PDGF) (Ek et al., 1982), transforming growth factor (TGF- $\alpha$ ) (Reynolds et al., 1981), and insulin-like growth factor I (IGF-I) (Jacobs et al., 1983, Rubin et al., 1983), implying that receptor kinase activity may represent a general mechanism in transmembrane signalling of hormones and growth factors. The purpose of the present Review is to describe the current status of functional and structural properties of insulin receptors in vertebrates. We will briefly summarize the functional properties of insulin receptors in metabolic regulation and insulin degradation. We emphasize the new advances in our knowledge about the insulin receptor protein structure and the recent discovery of the protein kinase activity of the receptor. Finally, the structural and functional heterogeneity of insulin receptors will be discussed.

\section{Functional properties of insulin receptor}

Earlier suggestions that insulin induces its biological actions at the plasma membrane level via combination with receptors of protein nature have been confirmed in a large number of studies of ${ }^{125}$ I-insulin binding during the last 15 years. Following the development of bioactive radioiodinated insulin preparations many experiments were performed assessing the binding kinetics of ${ }^{125}$ I-insulin on intact cells or purified plasma membranes from several tissues. The receptor binding of insulin is characterized by high affinity $\left(K_{\mathrm{D}} \sim 1.0 \mathrm{nM}\right)$ and marked specificity because only insulin and its analogues inhibit binding of ${ }^{125} \mathrm{I}$-insulin. The initially simple model of a reversible, bimolecular and nonco-operative interaction between receptor and insulin (Gammeltoft \& Gliemann, 1973) has been revised to include the existence of multiple affinity states (de Meyts et al., 1976; Gammeltoft et al., 1978). Thus, the insulin receptor exhibits negative co-operativity, as shown in experiments where binding affinity decreased with increasing receptor occupancy (de Meyts et al., 1976). In addition, formation of a high-affinity state or positive co-operativity was observed at low receptor occupancies (Gammeltoft et al., 1978; Donner \& Corin, 1980; Marsh et al., 1984). The molecular basis of these affinity changes is unknown, but the fact that they are also present in solubilized receptor preparations (Harrison et al., 1978) may suggest that they result from conformational changes within a bivalent insulin receptor structure (Pang \& Schafer, 1984; Czech, 1984).

The interaction of insulin with its receptor induces a variety of biological responses on membrane transport, cell metabolism and growth promotion. However, receptor binding of insulin is irreversible because of degradation of receptor-bound insulin following endocytosis ('internalization') of the insulin-receptor complex

Abbreviations used: EGF, epidermal growth factor; IGF, insulin-like growth factor; PGDF, platelet-derived growth factor; TGF, transforming growth factor.

Vol. 235 


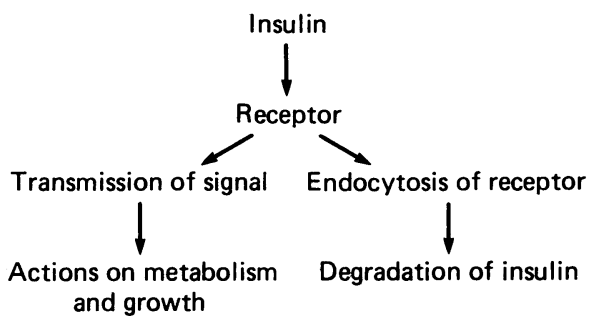

Fig. 1. Functional roles of insulin receptors in insulin action and degradation

(Fig. 1). The dual role of insulin receptors in metabolic regulation and hormone degradation is based on two kinds of experimental evidence: (1) that receptor occupancy elicits biological effects (Gliemann et al., 1975) and leads to insulin degradation (Terris \& Steiner, 1975) and (2) that modifications of receptors by trypsin or antibodies to insulin receptors are followed by reduced insulin action (Kono \& Barham, 1971; Kahn et al., 1977) and impaired proteolysis of insulin (Terris \& Steiner, 1975). Morphological and biochemical studies have provided evidence that receptor-bound insulin is translocated from the surface to the interior of the cell (for reviews see Gorden et al., 1980; Bergeron et al., 1985). Endocytosis of ${ }^{125} \mathrm{I}$-insulin into small cytoplasmic vesicles has been shown by electron-microscopic autoradiography (Carpentier et al., 1979) and subcellular fractionation (Suzuki \& Kono, 1979). It seems likely that insulin is degraded after internalization of the insulin-receptor complex, whereas the receptor is recycled back to the plasma membrane (Fehlmann et al., 1982). In conclusion, the insulin receptor mediates cellular insulin actions as well as proteolytic degradation of insulin, processes which involve signal transmission from receptor to membrane carriers and intracellular enzymes, regulation of receptor affinity, and internalization of receptor and hormone. The molecular mechanism is not clear, but recent progress regarding receptor structure and function might improve our understanding of insulin action.

\section{Insulin receptor structure}

The insulin receptor is an integral membrane glycoprotein $\left(M_{\mathrm{r}} \sim 300000\right)$ composed of two $\alpha$-subunits $\left(M_{\mathrm{r}} \sim 130000\right)$ and two $\beta$-subunits $\left(M_{\mathrm{r}} \sim 95000\right)$ linked by disulphide bonds (Fig. 2). The model is based on application of biosynthetic, cell-surface or affinity labelling of the receptor (Yip et al., 1978; Jacobs et al., 1979; Van Obberghen et al., 1981; Pilch \& Czech, 1979; Siegel et al., 1981). With affinity labelling the $\alpha$-subunit is labelled predominantly by radioactive insulin when compared with the $\beta$-subunit, the labelling of which is much weaker (Massagué et al., 1981), or even absent (Jacobs et al., 1979). This suggests that the insulin binding site is located on the $\alpha$-subunit of the receptor oligomer. Recent studies (see below) have shown that the $\beta$-subunit is an insulin-sensitive protein kinase which phosphorylates tyrosine residues on the $\beta$-subunit ('autophosphorylation') as well as other substrates. Thus, the insulin receptor is composed of subunits which separately display regulatory and catalytic activity.

Several authors have attempted to purify the insulin receptor for further structural analysis. The protocols used were mainly based on affinity chromatography using agarose conjugated with lectins such as concanavalin or wheat-germ agglutinin, followed by insulin-agarose (Cuatrecasas, 1972; Jacobs et al., 1977; Siegel et al., 1981). Three laboratories succeeded in purifying the receptor from placental membranes (Fujita-Yamaguchi et al., 1983; Roth et al., 1983b; Petruzzelli et al., 1984). The pure insulin receptor has a binding capacity of $1.1-1.5 \mathrm{~mol}$ of insulin $/ \mathrm{mol}$ of receptor $\left(M_{\mathrm{r}} \sim 300000\right)$, and protein kinase activity with $V_{\max }$ of $80 \mathrm{mmol} / \mathrm{min}$ per $\mathrm{mg}$ (using angiotensin as substrate; Petruzzelli et al., 1984).

Recently, the amino-acid sequence of the human insulin receptor precursor was deduced from human placental cDNA clones (Ullrich et al., 1985; Ebina et al., 1985). This achievement was based on $N$-terminal sequences obtained for both $\alpha$ - and $\beta$-subunits of the purified receptor, which were used for design of single long synthetic DNA probes and hybridization screening

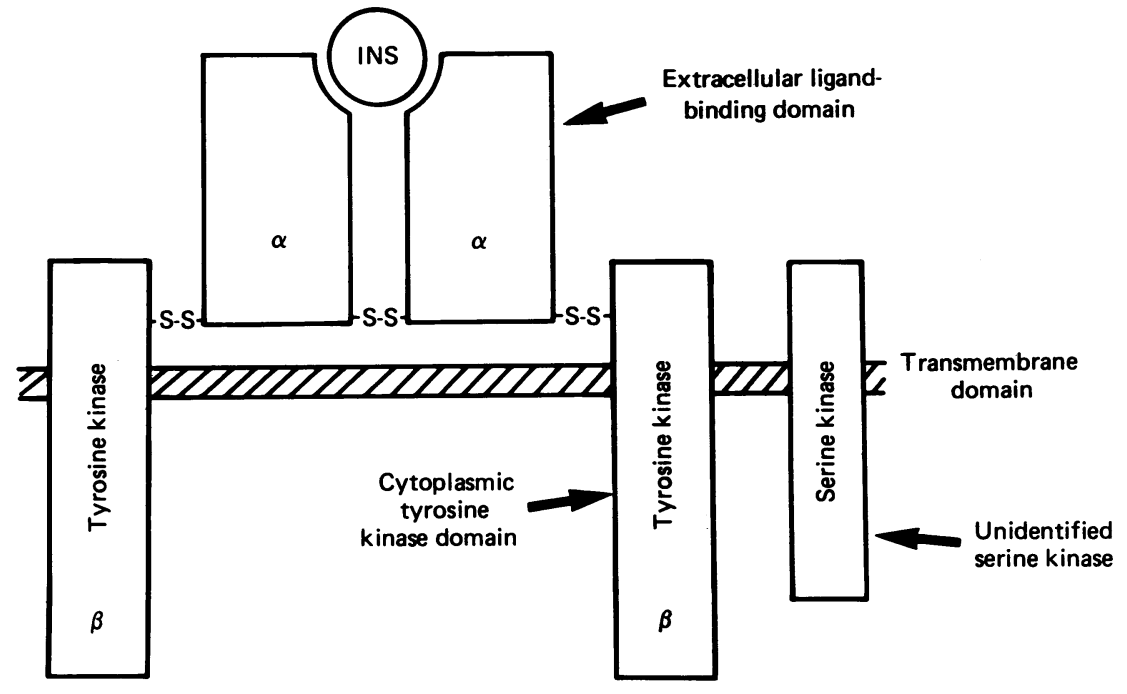

Fig. 2. Schematic model of the insulin receptor kinase complex 
of a DNA library to identify human insulin receptor cDNA clones. Nucleotide sequence analysis of cDNA positive clones which hybridized with both $\alpha$ - and $\beta$-subunit DNA probes revealed a 5181 base-pair-long sequence which coded for 1382 amino acids, including a 27-residue signal peptide. This is the amino-acid sequence of the insulin receptor single chain precursor, composed of an $N$-terminal $\alpha$-subunit (735 residues) followed by a $\beta$-subunit (620 residues) and an intervening peptide composed of four basic amino acids (Arg-Lys-Arg-Arg), which probably represents the cleavage site for the receptor precursor processing enzyme (Ullrich et al., 1985; Ebina et al., 1985). The $\alpha$-chain is largely hydrophilic with a few short hydrophobic stretches, and is probably extracellular. It contains sequences for asparagine $N$-linked glycosylation and the unusually large number of 37 cysteine residues. The $\beta$-chain contains a sequence of 23-26 hydrophobic amino acids, probably representing a single transmembrane region dividing the $\beta$-subunit in a shorter extracellular portion, which links the $\alpha$-subunit through disulphide bridges, and a longer cytoplasmic part (see Fig. 2).

The $\alpha$-subunit shows some similarities with the extracellular part of the EGF receptor, in particular in the domain rich in cysteine which may form disulphide bonds resulting in a compact structure (Ullrich et al., 1984). It seems probable that these cysteine-rich clusters may contain the ligand-binding region, as in the low-density lipoprotein receptor (Yamamoto et al., 1984).

The cytoplasmic part of the insulin receptor $\beta$-subunit shows some homology with other tyrosine-specific kinases like the src oncogene kinases (Heldin \& Westermark, 1984; Hunter, 1984), and the EGF-receptor kinase (Downward et al., 1984; Ullrich et al., 1984). The similarities in sequence include the ATP-binding site and the residues essential for kinase activity, as well as tyrosine residues which can be phosphorylated, demonstrating that the insulin receptor is a member of the src family of tyrosine kinases. No cellular proto-oncogene has yet been identified which is identical with the insulin receptor $\beta$-subunit as is the case for the EGF receptor and $v$-erb $B$ oncogene product (Downward et al., 1984; Ullrich et al., 1984), although one region of the insulin receptor $\beta$-subunit (51 residues) is practically identical with a portion of the $v$-ros protein (Nickameyer \& Wang, 1985). It is possible that the insulin receptor is the cellular homologue of the $v$-ros transforming protein, which has $M_{\mathrm{r}} \sim 68000$, tyrosine kinase activity and a hydrophobic transmembrane region at the $N$-terminus.

In conclusion, the amino-acid sequence of the insulin receptor substantiates the model that the insulin-binding site is located on the $\alpha$-subunit, and that the $\beta$-subunit is a tyrosine kinase. Future studies will define the residues interacting with insulin and the phosphorylation sites at tyrosine as well as serine residues which might help in understanding the transmembrane signalling of the insulin receptor.

\section{The insulin receptor kinase}

In intact cells, insulin stimulates the phosphorylation of its receptor $\beta$-subunit. This was first demonstrated in rat hepatoma cells and human IM9 lymphoblasts (Kasuga et al., 1982a) and later in freshly isolated rat hepatocytes (Van Obberghen \& Kowalski, 1982). In these experiments, cells were preincubated with $\left[{ }^{32} \mathrm{P}\right] \mathrm{P}_{\mathrm{i}}$ to label cellular ATP, solubilized in detergent, and the glyco- proteins purified on wheat-germ-agglutinin-agarose. Immunoprecipitation of phosphorylated proteins by antibodies to insulin receptors followed by SDS/ polyacrylamide-gel electrophoresis under reducing conditions and autoradiography revealed a labelled band $\left(M_{\mathrm{r}} \sim 95000\right)$, the phosphorylation of which was stimulated by insulin. Its identity with the insulin receptor $\beta$-subunit was established for the following reasons. First, non-immune serum did not precipitate a band with a similar electrophoretic mobility. Second, the molecular size was identical with that previously determined using biosynthetic, cell surface, and affinity labelling methods (Jacobs et al., 1979; Van Obberghen et al., 1981; Massagué et al., 1981).

Subsequently, insulin-stimulated phosphorylation of the $\beta$-subunit of insulin receptor was demonstrated in cell-free systems using $\left[\gamma^{32} \mathrm{P}\right] \mathrm{ATP}$ in solubilized and partially purified receptor preparations from rat liver (Fig. 3) and human placenta, and analysis of phosphoaminoacids showed predominant labelling of phosphotyrosine and to a smaller degree of phosphoserine (Kasuga et al., 1982b,; Van Obberghen et al., 1983: Avruch et al., 1982; Petruzzelli et al., 1982; Roth \& Cassell, 1983; Shia \& Pilch, 1983). In intact cells phosphoaminoacid analysis of the phosphorylated $\beta$ subunit of insulin receptors showed phosphoserine, phosphothreonine and phosphotyrosine under basal conditions. Insulin induced a rapid, several-fold increase in ${ }^{32} \mathrm{P}$ incorporation in tyrosine, followed by a slower rise

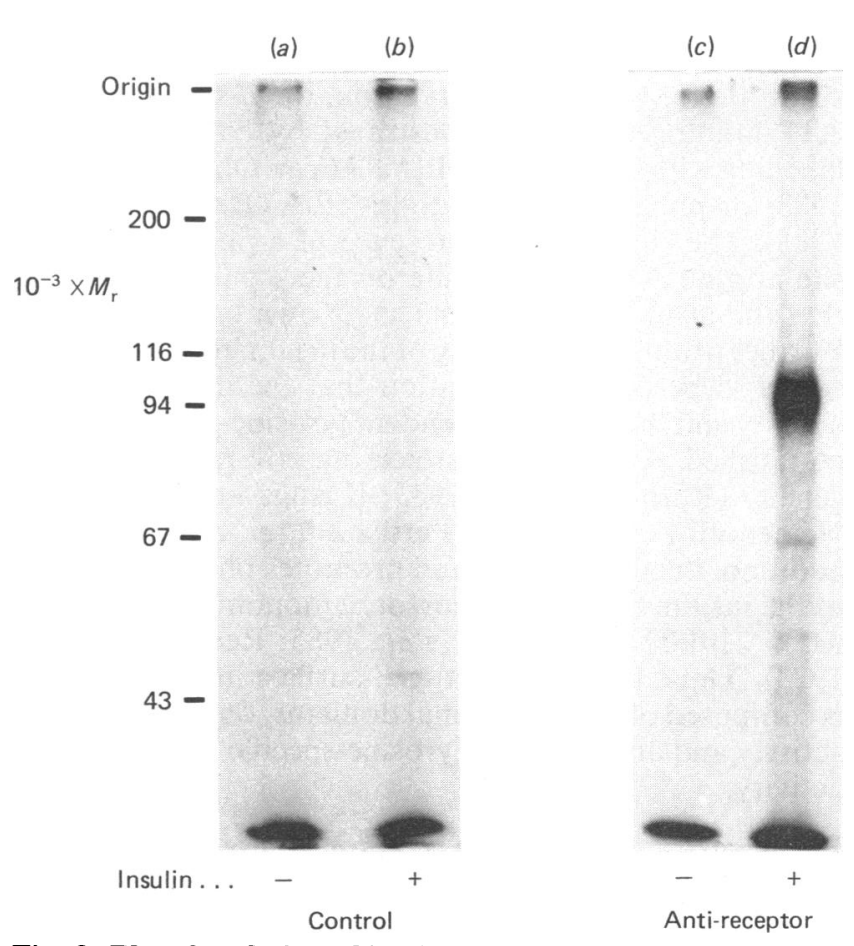

Fig. 3. Phosphorylation of insulin receptors

Partially purified receptors from rat liver were incubated $30 \mathrm{~min}$ at $20^{\circ} \mathrm{C}$ in the absence $(a$ and $c$ ) or presence of insulin $(0.1 \mu \mathrm{M})(b$ and $d)$ and phosphorylated with $\left[\gamma^{32}\right.$ P]ATP. The phosphoproteins were immunoprecipitated with antiserum to insulin receptor ( $c$ and $d$ ) or normal serum ( $a$ and $b$ ) and analysed by SDS/ polyacrylamide-gel electrophoresis followed by autoradiography (data from Van Obberghen \& Kowalski, 1982). 
in labelling of phosphoserine (Kasuga et al., 1982c; Gazzano et al., 1983; Zick et al., 1983a; Pang et al., 1985; White et al., 1985).

The insulin receptor exhibits insulin-dependent tyrosine-kinase activity. This was demonstrated in cell-free systems with detergent-solubilized and highly purified receptors obtained from various tissues. The purification scheme was based on sequential affinity chromatography on wheat germ agglutinin- and insulin-agarose (FujitaYamaguchi et al., 1983; Roth et al., 1983b; Petruzzelli et al., 1984; Nemenoff et al., 1984; Kasuga et al., 1983a,b). Alternatively, the lectin-purified receptors were immunoprecipitated with antibodies to insulin receptors obtained from patients with severe insulin-resistance and acanthosis nigricans (Kasuga et al., 1982b; Van Obberghen et al., 1983), or monoclonal IgG directed against insulin receptors (Roth et al., 1982; Kull et al., 1983). These purified receptor preparations exhibited insulinstimulated protein kinase activity which catalysed phosphorylation of both the $\beta$-subunit and exogenous substrates like casein, histones and synthetic tyrosinecontaining peptides. In contrast with the partially purified receptor, the phosphorylation occurred exclusively on tyrosine residues in highly purified receptors under basal conditions, and the insulin stimulatory action was accounted for by a several-fold increase in phosphotyrosine (Avruch et al., 1982; Petruzzelli et al., 1982, 1984; Gazzano et al., 1983; Kasuga et al., 1983a; Roth \& Cassell, 1983; Shia \& Pilch, 1983). Thus, the tyrosine kinase is a constituent of the insulin receptor, whereas the serine kinase is non-covalently associated with the receptor (Fig. 2). In addition to being the principal substrate for autophosphorylation, the $\beta$-subunit has an ATP-binding site as demonstrated by covalent affinity labelling with oxidized [ $\left.\alpha{ }^{-32} \mathrm{P}\right] \mathrm{ATP}$ (Van Obberghen $e t$ al., 1983 ) or photoreactive azido-[ $\left.\alpha-{ }^{32} P\right] A T P$ (Shia \& Pilch, 1983). The simultaneous presence of a phosphorylation site and an ATP-binding site on the $\beta$-subunit suggests that the insulin receptor acts as its own tyrosine kinase. Further proof of the identity of the insulin receptor kinase seems to be the demonstration that the insulin-binding activity and the insulin-dependent tyrosine-kinase activity co-purified at a constant stoichiometric ratio to homogeneity (Roth \& Cassell, 1983; Kasuga et al., 1983a, $b$; Nemenoff et al., 1984; Petruzzelli et al., 1984). In addition, insulin binds to and promotes phosphorylation of the insulin receptor precursor, a monomeric protein of $M_{\mathrm{r}} \sim 210000$ (Blackshear et al., 1983; Rees-Jones et al., 1983). Thus, the functional cell-surface insulin receptor is composed of two functional domains, one with binding activity and another with tyrosine-specific protein kinase activity.

\section{Biochemistry of the insulin receptor kinase}

Following the identification of the protein kinase activity of the insulin receptor $\beta$-subunit, its biochemical properties have been investigated (Table 1). These included temperature dependence, metal ion requirements, nucleotide and substrate specificity, and kinetic parameters of the phosphorylation reaction. In the absence of insulin, phosphorylation occurred slowly, but addition of insulin (100 nM) stimulated rapidly the incorporation of ${ }^{32} \mathrm{P}$ from $\left[\gamma^{-32} \mathrm{P}\right] \mathrm{ATP}$ into the $\beta$-subunit of the receptor. Within $30 \mathrm{~s}$ at $22^{\circ} \mathrm{C}$, autophosphorylation of the insulin-stimulated receptor reached $50 \%$ of maximum and a steady state value was reached after about $10 \mathrm{~min}$ (White et al., 1984). Even at $4^{\circ} \mathrm{C}$, the phosphorylation was rapid; the ${ }^{32} \mathrm{P}$ content of the receptor reached half-maximal level by $5 \mathrm{~min}$ and maximum after about 20 min (Zick et al., 1983c).

As with the EGF-stimulated phosphorylation of the EGF receptor (Carpenter et al., 1979; Pike et al., 1984), $\mathrm{Mn}^{2+}$ was the most potent cation in augmenting the insulin-stimulated phosphorylation of the insulin receptor (Avruch et al., 1982; Petruzzelli et al., 1984; White et al., 1984; Zick et al., 1983c; Pike et al., 1984). The effect of $\mathrm{Mn}^{2+}$ was maximal at concentrations above $2 \mathrm{mM}$ and constant up to $10 \mathrm{~mm}$ (Pike et al., 1984), but showed a complex relationship with the ATP concentration (see below). $\mathrm{Mg}^{2+}$ was also effective, but concentrations above $15 \mathrm{~mm}$ were required for a maximal effect. However, the insulin-stimulated kinase showed greater activity in the presence of a combination of $2 \mathrm{mM}-\mathrm{Mn}^{2+}$ and $12 \mathrm{mM}-\mathrm{Mg}^{2+}$ than when either metal ion was used alone (Pike et al., 1984). $\mathrm{Ca}^{2+}$ as well as $\mathrm{Zn}^{2+}$ and $\mathrm{Cr}^{2+}$ were totally ineffective, whereas $\mathrm{Co}^{2+}(2 \mathrm{mM})$ had some effect (Avruch et al., 1982; Zick et al., 1983c). This ion dependency is characteristic of tyrosine kinases compared with serine kinases and threonine kinases (Cohen, 1982).

In the cell-free system, the source of phosphate used to phosphorylate the $\beta$-subunit was identified as ATP (Kasuga et al., 1982b), and the $K_{\mathrm{m}}$ value for ATP of the insulin-stimulated receptor kinase was determined as 30-150 $\mu \mathrm{M}$ (Petruzzelli et al., 1984; Nemenoff et al., 1984; White et al., 1984; Pike et al., 1984). No other nucleoside triphosphate (GTP, CTP, dTTP or UTP) competed with $\left[\gamma^{-32} \mathrm{P}\right] \mathrm{ATP}$ in the receptor phosphorylation assay, whereas addition of ATP and ADP, but not AMP, gave significant inhibition of ${ }^{32} \mathrm{P}$ incorporation (Nemenoff et al., 1984; White et al., 1984; Pike et al., 1984). Cyclic AMP had no effect on the phosphorylation of the receptor (Petruzzelli et al., 1982; Nemenoff et al., 1984; Zick et al., 1983c). Thus, the insulin receptor kinase showed specificity for adenosine di- and tri-phosphates. As mentioned above, $\mathrm{Mn}^{2+}$ and ATP showed a complex relationship in their activation of the kinase. Kinetic data showed that $\mathrm{Mn}^{2+}$ acted predominantly by decreasing the $K_{\mathrm{m}}$, for ATP, presumably through binding to a specific regulatory site on the kinase rather than chelating with ATP. On the other hand, increasing ATP concentration decreased the $K_{\mathrm{m}}$, for $\mathrm{Mn}^{2+}$, showing that a high substrate concentration can activate the kinase even when the metal activator concentration is low (White et al., 1984).

The substrate specificity of the insulin receptor kinase was assessed using both naturally occurring proteins and synthetic peptides including histones, casein, tubulin, troponin, angiotensin II, angiotensin III inhibitor, $\beta$-lipotropin, pp60src (a gene product of the Rous sarcoma virus), anti-pp60src IgG, and several synthetic peptide fragments containing a tyrosine residue (Gazzano et al., 1983; Nemenoff et al., 1984; Kasuga et al., 1983b; Pike et al., 1984; Stadtmauer \& Rosen, 1983). In the proteins, phosphoaminoacid analysis showed only phosphorylation on tyrosine residues. Among the synthetic peptides, even the dipeptide Tyr-Arg was a substrate, although with very high $K_{\mathrm{m}}$ (Stadtmauer \& Rosen, 1983). The $K_{\mathrm{m}}$ values varied significantly among the substrates from $1 \mu \mathrm{M}$ to a value $>80 \mathrm{mM}$, but insulin acted by increasing the $V_{\max }$. with no alteration of $K_{\mathrm{m}}$ (Nemenoff et al., 1984; Kasuga et al., 1983b; Pike et al., 1984; Stadtmauer \& Rosen, 1983). The substrate specificity of 
Table 1. Major features of the insulin receptor kinase

Feature

References

1. Intrinsic to the receptor

ATP-binding site on the receptor $\beta$-subunit

Phosphorylation of highly purified receptors

Co-purification of insulin binding activity and insulin-stimulated kinase activity

Present whenever receptors present

2. Regulators

Insulin

ATP (phosphate donor)

$\mathrm{Mn}^{2+}, \mathrm{Mg}^{2+}$

3. Substrates

Receptor: autophosphorylation

Substrates: exogenous and endogenous

4. Phosphoamino acids in receptor

Intact cells: tyrosine and serine

Cell-free systems: predominantly tyrosine

5. Multiple sites phosphorylated on receptor $\beta$-subunit
Van Obberghen et al. (1983), Shia \& Pilch (1983)

Kasuga et al. (1982b), Van Obberghen et al. (1983), Avruch et al. (1982),

Petruzzelli et al. (1982), Roth \& Cassell (1983), Shia \& Pilch (1983)

Roth \& Cassell (1983), Kasuga et al. (1983a,b), Nemenoff et al. (1984),

Petruzzeli et al. (1984)

Kasuga et al. (1982a-c), Van Obberghen et al. (1983, 1985), Häring

et al. (1982, 1984b), Velicelebi \& Aiyer (1984), Burant et al. (1984),

Petruzzelli et al. (1982), Roth \& Cassell (1983), Shia \& Pilch (1983),

Grunberger et al. (1984a), Grigorescu et al. (1983), Gammeltoft et al.

(1984a), Rees-Jones et al. (1984), White et al. (1984), Gazzano et al.

(1985)

Kasuga et al. (1982a,b), Van Obberghen et al. (1983), Avruch et al. (1982), Petruzzelli et al. (1982)

Kasuga et al. (1982b), Petruzzelli et al. (1984), Nemenoff et al. (1984), White et al. (1984), Pike et al. (1984)

Avruch et al. (1982), Petruzzelli et al. (1984), White et al. (1984),

Zick et al. (1983c), Pike et al. (1984)

Kasuga et al. (1982b, 1983a,b), Van Obberghen et al. (1983), Roth et al. (1982, 1983b), Petruzzelli et al. (1984), Nemenoff et al. (1984)

Gazzano et al. (1983), Nemenoff et al. (1984), Kasuga et al. (1983b),

Pike et al. (1984), Stadtmauer \& Rosen (1983), Sadoul et al. (1985),

Rees-Jones \& Taylor (1985)

Gazzano et al. (1983), Kasuga et al. (1982c), Pang et al. (1985),

White et al. (1985)

Avruch et al. (1984), Petruzzelli et al. (1982, 1984), Gazzano et al. (1983),

Kasuga et al. (1983a), Roth \& Cassell (1983), Shia \& Pilch (1983)

Rosen et al. (1984), Yu \& Czech (1984), Yu et al. (1985), White et al. (1984) the insulin receptor kinase was similar to, but not identical with, that of the EGF receptor (Carpenter $e$ t al., 1979; Pike et al., 1984; Blackshear et al., 1984) and the pp60src kinases (Hunter, 1982), suggesting that they are members of a superfamily of tyrosine kinases which have diverged from a commion evolutionary origin.

It seems that the insulin receptor $\beta$-subunit is the best substrate for its own kinase. This conclusion is based on the observation that the $V_{\max }$. for autophosphorylation of the insulin receptor kinase was increased nearly 20 -fold by insulin (White et al., 1984), whereas the $V_{\max }$. values for other substrates were only increased 2-5-fold (Nemenoff et al., 1984; Kasuga et al., 1983b; Pike et al., 1984; Stadtmauer \& Rosen, 1983). Alternatively, it has been suggested that the kinase activity associated with the insulin receptor is increased by tyrosine phosphorylation of the receptor $\beta$-subunit (Rosen et al., 1983; Yu \& Czech, 1984; Yu et al., 1985). Phosphorylation on tyrosine residues induced by insulin leads to increased kinase activity, whereas dephosphorylation of the tyrosine residues by alkaline phosphatase is accompanied by a marked inhibition (Yu \& Czech, 1984). Thus, the autophosphorylation on tyrosine residues may play a key role in regulating the insulin receptor kinase. The additional phosphorylation of serine and threonine residues on the receptor by non-covalently associated kinases may also exert a regulatory role on insulin receptor kinase and binding activity (Czech, 1984).

\section{Role of receptor phosphorylation in insulin action}

The biological relevance of insulin receptor phosphorylation is not clear. It is possible that it plays a role in cellular processes such as receptor affinity regulation, hormone and receptor internalization and signal transmission. These phenomena are well-characterized (for reviews see Kahn et al., 1981; Jacobs \& Cuatrecasas, 1981; Gammeltoft, 1984), but their molecular mechanism is almost completely unknown. Most likely receptor regulation, internalization and transmembrane signalling are integrated events in insulin action; and receptor autophosphorylation per se is involved in transmission of the insulin message to cellular enzymes and transport carriers. At present, it is tempting to suggest that the covalent receptor modification is an early step in insulin action and that the increased kinase activity of the insulin receptor evoked by hormone binding would lead to phosphorylation-dephosphorylation of other cellular proteins, and through the generation of a cascade of reactions this would result in the final effects of insulin. Five requirements should be fulfilled by the insulininduced receptor kinase activation and autophosphorylation in order to be involved in insulin action.

First, the insulin dose-response relationship of the kinase should be within the physiological range and correlate with that of the binding to the receptor. Several authors found that the kinase activation was half-maximal 
at an insulin concentration of $2-5 \mathrm{nM}\left(\sim \mathrm{ED}_{50}\right.$; effective dose for $50 \%$ activation), which corresponded to the apparent $K_{\mathrm{d}}$ of the receptor-insulin complex as determined with the same preparations of solubilized receptor of varying purity obtained from human placenta (Kasuga et al., 1982c; Avruch et al., 1982; Shia \& Pilch, 1983; Petruzzelli et al., 1984; Nemenoff et al., 1984; Pike et al., 1984; Rosen et al., 1983; Sadoul et al., 1985). In contrast, a dissociation between the dose-response curves of insulin binding and kinase activation was observed with soluble receptors from rat liver and human erythrocytes (Zick et al., 1983c; Grigorescu et al., 1983). In these studies, the apparent $K_{d}$ exceeded the $\mathrm{ED}_{50}$ by a factor of 3-10, suggesting that the phenomenon of 'spare receptors' observed for other insulin actions (for review see Gammeltoft, 1984) is also applicable for kinase activation. It is not clear whether the different findings are explained by differences in the tissues, purification procedures, or assay methods used. In conclusion, the receptor kinase is activated by insulin concentrations within a physiological range corresponding to receptor binding.

Secondly, the receptor kinase should be capable of phosphorylating other cellular substrates than the receptor itself, in order to propagate the insulin response. As discussed in detail above, the insulin receptor kinase is capable of phosphorylating a number of substrates on tyrosine residues in vitro, although none of the proteins tested are physiological substrates (Gazzano et al., 1983; Petruzzelli et al., 1984; Kasuga et al., 1983b; Pike et al., 1984; Stadtmauer \& Rosen, 1983). Recently, two laboratories, independently, identified a cellular protein substrate of $M_{\mathrm{r}} \sim 110000-120000$ for the insulin receptor kinase in wheat-germ-agglutinin purified glycoproteins from rat liver and rabbit brown adipose tissue (Sadoul et al., 1985; Rees-Jones \& Taylor, 1985).

The naturally occurring glycoprotein appears as a monomeric structure, and is not part of the insulin receptor itself, because it was not immunoprecipitated by highly specific antibodies to insulin receptor. Phosphorylation of the $M_{\mathrm{r}} \sim 110000$ protein and autophosphorylation of the receptor $\beta$-subunit $\left(M_{\mathrm{r}} \sim 95000\right)$ were stimulated by insulin in a remarkably similar dosedependent fashion with $\mathrm{ED}_{50}$ of $1 \mathrm{nM}$. Further kinetic studies suggested that the phosphorylation of the $M_{\mathrm{r}} \sim 110000$ protein occurred after autophosphorylation of the insulin receptor kinase (Sadoul et al., 1985). The nature and function of this endogenous substrate is yet unknown, as well as the intriguing question whether it displays kinase or phosphatase activity.

In intact cells, the rapid insulin-stimulated phosphorylation of its receptor on tyrosine residues is followed by a slower serine phosphorylation (Kasuga et al., 1982c; Pang et al., 1985; White et al., 1985). Furthermore, in a cellfree system of partially purified insulin receptor, some laboratories have reported that insulin stimulates phosphorylation of both tyrosine and serine residues on its receptor (Kasuga et al., 1982c; Zick et al., 1983a; Yu \& Czech, 1984) as well as on exogenous substrates (Gazzano et al., 1983). The serine kinase is non-covalently associated with the receptor, and is removed during further purification, because the highly purified receptor displayed only tyrosine kinase activity (Kasuga et al., 1982c, 1983b; Gazzano et al., 1983; Petruzzelli et al., 1984; Nemenoff et al., 1984). The relationship between the two protein kinase activities associated with the

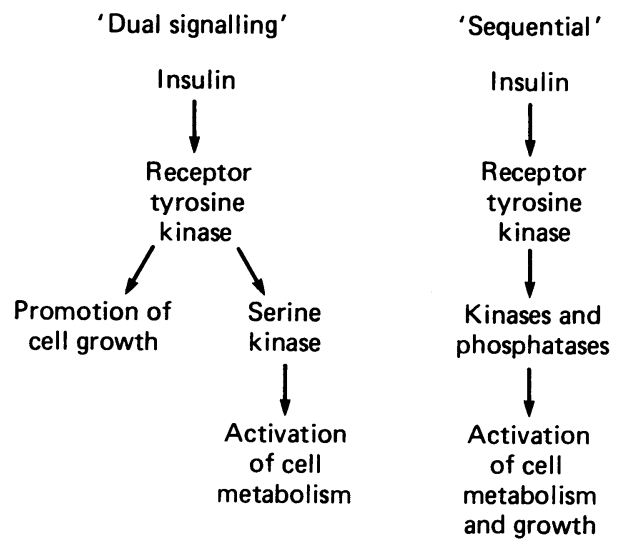

Fig. 4. Putative roles of receptor-associated tyrosine and serine kinases in insulin control of cell metabolism and growth

receptor and their cellular role remains to be established. Two possibilities exist (Fig. 4), one in which both kinases serve separate cellular functions, and another one with sequential activation of the kinases (Van Obberghen et al., 1985).

The first model implies that the tyrosine-specific enzyme activity is involved in insulin's growth-promoting action similar to the tyrosine phosphorylations mediating the cellular responses to growth factors such as EGF (Cohen et al., 1980), PDGF (Ek et al., 1982) and TGF- $\alpha$ (Reynolds et al., 1981) and several cellular and retroviral oncogene proteins (Hunter, 1982, 1984; Bishop, 1983; Heldin \& Westermark, 1984). In contrast, the serine kinase would play a role in insulin's metabolic actions. All kinases involved in the control of intermediary metabolism are indeed serine- or threonine-specific (Denton et al., 1981; Cohen, 1982), and phosphoserine and phosphothreonine constitute about $99.97 \%$ of all phosphorylated amino acids, phosphotyrosine accounting for the remaining $0.03 \%$ (Hunter \& Sefton, 1980). In the second model, the two kinases are activated sequentially. Insulin binding to its receptor leads to activation of the constituent tyrosine kinase, which then induces activation of the receptor-associated serine kinase and this last one accounts for the generation of cellular responses to insulin. Future work should be directed towards the identification of the serine kinase.

The third criterion is that of reversibility of insulin receptor phosphorylation. To exert a regulatory function, the phosphorylated and activated receptor kinase should return to basal activity through a dephosphorylation reaction. Solubilized, lectin-purified receptors from rat liver membranes contained phosphatase activity, which slowly reduced the ${ }^{32} \mathrm{P}$ content of the phosphorylated receptor, and which was insulin-independent (Häring et al., 1984a; Kowalski et al., 1983; Zick et al., 1983b). The significance of this reaction is difficult to ascertain, in particular because a $2 \mathrm{~h}$ incubation at $22^{\circ} \mathrm{C}$ was required for complete dephosphorylation of the receptor (Kowalski et al., 1983). A different approach was taken by incubation of the phosphorylated insulin receptor with alkaline phosphatase, which resulted in removal of about $50 \%$ of the phosphotyrosine in the $\beta$-subunit, and about $65 \%$ reduction in kinase activity, suggesting that dephosphorylation is accompanied by deactivation of the receptor kinase (Zick et al., 1983b; Yu \& Czech, 1984). These observations demonstrate that the insulin receptor 
kinase can be deactivated through dephosphorylation of phosphotyrosine residues.

The fourth criterion regards the specificity of the insulin effect on its receptor kinase. Several insulin analogues, including porcine proinsulin, des-octapeptideinsulin, des-alanine-des-asparagine-insulin, guinea pig insulin, insulin-like growth factor II and covalently linked insulin dimers stimulated receptor phosphorylation with potencies relative to porcine insulin which were identical with their relative binding affinities and potencies in other assay systems (Kasuga et al., 1982b; Petruzzelli et al., 1982; Zick et al., 1983c; Pike et al., 1984; Grigorescu et al., 1983; Roth et al., 1984). Furthermore, polyclonal antisera directed against the insulin receptor, which show insulin-like effects in several cell types, were also able to stimulate the tyrosine-specific kinase associated with the receptor (Petruzzelli et al., 1982; Zick et al., 1984). However, some antibodies were inactive, although they showed both insulin-like effects in intact cells and interaction with receptors in cell-free preparations (Zick et al., 1984; Simpson \& Hedo, 1984). The reason for this discrepancy is not clear, but a possible explanation is that activation of the receptor-associated tyrosine kinase mediates the growth activity of insulin and not the metabolic actions (cf. Fig. 4). Finally, other hormones which do not bind to the insulin receptor, including EGF, which activates its own receptor kinase, had no effect on insulin receptor kinase activity (Pike et al., 1984; Zick et al., 1983b). In conclusion, the insulin effect on phosphorylation of its own receptor has the affinity and specificity of a typical insulin receptor mediated event.

Finally, the kinase activity of the insulin receptor seems to be a fundamental property, since whenever insulin receptors are present, insulin-stimulated autophosphorylation of its receptor $\beta$-subunit can be demonstrated. This applies to all tissues investigated so far, including liver (Kasuga et al., 1982b; Van Obberghen et al., 1983), adipose tissue (Häring et al., 1982; Velicelebi \& Aiyer, 1984), muscle (Burant et al., 1984; Häring et al., 1984b; Le Marchand-Brustel et al., 1985), placenta (Petruzzelli et al., 1982; Roth \& Cassell, 1983; Shia \& Pilch, 1983), lymphocytes (Grunberger et al., 1984a), erythrocytes (Grigorescu et al., 1983), fibroblasts (Van Obberghen et al., 1985), brain cortex (Gammeltoft et al., 1984a; Rees-Jones et al., 1984), and various cell lines like IM 9 lymphoblasts (Kasuga et al., 1982a), 3T3-L1 adipocytes (Petruzzelli et al., 1982), hepatoma cells (Kasuga et al., 1982a, c; White et al., 1984) and insulinoma cells
(Gazzano et al., 1985). Thus, the insulin-sensitive kinase is a general feature of the insulin receptor.

Additional evidence for a role of insulin receptor kinase in insulin action was obtained by two kinds of observations (Table 2). First, the receptor kinase activity is impaired in cells from various insulin-resistant states including the syndrome of insulin resistance and acanthosis nigricans, type A (Grunberger et al., 1984a, b; Grigorescu et al., 1984), melanoma cell cultures (Häring et al., 1984c), gold thioglucose obese mice (Le MarchandBrustel et al. 1985), and streptozotocin diabetic rats (Kadowaki et al., 1984). Second, insulinomimetic agents like vanadate, concanavalin $\mathbf{A}$, wheat germ agglutinin, and trypsin, which act via the insulin receptor, increased the receptor autophosphorylation (Kowalski et al., 1983; Tamura et al., 1983a, b; Roth et al., 1983a).

In conclusion, five criteria are fulfilled which establish the kinase as fundamental property of the insulin receptor and strongly suggest its important role in insulin action. Data from several laboratories suggest that receptor phosphorylations are involved in insulin receptor autoregulation and in the transmission of the insulin signal. At present there is no information on a role in insulin receptor internalization. It has been proposed that tyrosine phosphorylation of the $\beta$-subunit regulates its kinase activity, whereas receptor phosphorylation on serine and threonine residues could play a role in modulation of affinity of the $x$-subunit. Furthermore, phosphorylation of an endogenous substrate on tyrosine and serine might represent the secondary event leading to insulin actions on metabolism and growth.

\section{Heterogeneity of insulin receptors}

Insulin elicits a diversity of biological responses in a large number of vertebrate tissues. The regulatory effects include activation of transport processes for glucose, amino acids and ions, regulation of enzyme activities involved in carbohydrate, lipid and protein metabolism and modulation of cell growth. These insulin actions show a variation in their time of onset and their dose-response relationship ranging from acute effects (seconds to minutes) on transport and enzyme systems at low insulin concentrations to slow promotion (hours) of cell proliferation at higher insulin levels (Kahn et al., 1981; Denton et al., 1981; Czech, 1984). The various effects of insulin on different cell types are mediated by membrane receptors which are homologous in their structural and functional characteristics. However,

Table 2. Evidence for a role of insulin receptor kinase in insulin action

$\begin{array}{ll}\text { Feature References } & \end{array}$

Impaired insulin receptor kinase activity in insulin-resistant states

1. Syndrome of insulin resistance and acanthosis nigricans type $\mathbf{A}$

2. Cultured melanoma cells

3. Mice rendered obese by goldthioglucose

4. Streptozotocin diabetic rats
Grunberger et al. (1984a,b), Grigorescu et al. (1984)

Häring et al. (1984c)

Le Marchand-Brustel et al. (1985)

Kadowaki et al. (1984)

Increased insulin receptor phosphorylation induced by insulinomimetic agents

1. Vanadate

2. Trypsin

3. Concanavalin A

4. Wheat germ agglutinin
Tamura et al. (1983a), Kowalski et al. (1983)

Tamura et al. (1983b)

Roth et al. (1983)

Roth et al. (1983) 
experimental evidence has accumulated that insulin receptors also show striking tissue and species differences in their subunit size, binding kinetics, and peptide specificity, whereas their tyrosine kinase activity is more conserved. This heterogeneity may be linked to the different physiological actions of insulin in various tissues, and three examples will be discussed.

Two of the major insulin targets, liver and fat, show significant differences in receptor binding kinetics. The association rate and binding affinity of receptor-insulin interaction is higher in liver than in fat cells $\left(K_{\mathrm{d}} \sim 0.5 \mathrm{nM}\right.$ versus $3.0 \mathrm{nM}$ ) (Gammeltoft \& Gliemann, 1973; Gammeltoft et al., 1978). Furthermore, the coupling between receptors and metabolic effects of insulin is different. Binding and action are almost linearly coupled in liver, whereas fat cells display the 'spare receptor' phenomenon (Gliemann et :al., 1975). It seems likely that receptors in liver and fat adapt to different ambient insulin concentrations in the portal and extraportal circulation. In liver the values of $K_{d}$ for receptor binding of insulin and $\mathrm{ED}_{50}$ for insulin-stimulated glycogenesis are within the physiological range of concentrations of portal insulin. In fat cells the $\mathrm{ED}_{50}$ for insulin-stimulated glucose transport is similar to insulin levels in peripheral venous plasma, but the value of $K_{\mathrm{d}}$ for receptor binding is about 50 times higher. Thus, under physiological conditions, maximal effects are obtained by receptor occupancies of $\sim 90 \%$ in liver versus $\sim 5-10 \%$ in fat cells (Gammeltoft, 1984). Structural differences may also exist because antigenic determinants and glycosylation of insulin receptors in liver and fat cells seem to vary whereas the molecular size and subunit composition are similar (Kahn et al., 1977; Pottick et al., 1981).

Insulin receptors are widespread in mammalian brain (Havrankova et al., 1978; Hendricks et al., 1983) and recent observations suggest that they may represent a structural and functional receptor subtype among insulin receptors (for review see Gammeltoft et al., 1985a). The electrophoretic mobility of brain receptor $\alpha$-subunits is significantly smaller than in other tissues $\left(M_{\mathrm{r}} \sim 115000\right.$ versus 130000) (Fig. 5a) whereas that of the $\beta$-subunit $\left(M_{\mathrm{r}} \sim 94000\right)$ is similar (Fig. 5b) (Yip et al., 1980; Heidenreich et al., 1983; Gammeltoft et al., 1984a; Rees-Jones et al., 1984). The binding properties show striking differences in comparison with other cell types, because negatively co-operative interactions are absent (Gammeltoft et al., 1984b; Van Schravendijk et al., 1984) and the insulin specificity is different (Gammeltoft et al., $1984 b, 1985 b)$. Thus, insulin from a hystricomorph rodent, the coypu, and insulin-like growth factors (IGF I and II) are bound with higher affinity in brain than in liver and fat cells. This observation may suggest that brain insulin receptors mediate the growth activity of insulin because hystricomorph insulins and IGFs are more potent growth promotors than other insulin analogues (King \& Kahn, 1981). Indeed, studies in fetal rat brain suggest that insulin may act as a growth factor in nervous tissues rather than as metabolic regulator, as discussed elsewhere (Gammeltoft et al., 1985a). It should be emphasized that insulin and IGFs interact with separate receptors in the central nervous system (Gammeltoft et al., 1985b).

Finally, insulin receptors in human IM-9 lymphoblasts show different characteristics in comparison to those in liver and fat cells regarding faster association and dissociation kinetics of receptor-bound insulin, complete absence of receptor-mediated insulin degradation and a greater $M_{\mathrm{r}}$ of $\alpha$ - and $\beta$-subunits (Sonne \& Gliemann, 1980; Van Obberghen et al., 1981). The observed differences may indicate that the insulin receptors of transformed cell lines in culture generally have greatly altered properties which may be linked to a different role of insulin in these cells. It should be added that the rate of receptor-mediated insulin degradation shows species variations because it is much faster in rat tissues than in human fat cells and monocytes (Beck-Nielsen \& Pedersen, 1979; Pedersen et al., 1981). The significance of these variations is not clear at present.

In conclusion, insulin receptors show a structural and functional heterogeneity probably related to the diversity of insulin action. A resolution of the receptor amino acid sequence in tissues other than human placenta (Ullrich et al., 1985; Ebina et al., 1985) might help in understanding the structure-function relationship of the insulin receptor.

\section{Summary and conclusions}

The insulin receptor is an integral membrane glycoprotein $\left(M_{\mathrm{r}} \sim 300000\right)$ composed of two $\alpha$-subunits $\left(M_{\mathrm{r}} \sim 130000\right)$ and two $\beta$-subunits $\left(M_{\mathrm{r}} \sim 95000\right)$ linked by disulphide bonds. This oligomeric structure divides the receptor into two functional domains such that $\alpha$-subunits bind insulin and $\beta$-subunits possess tyrosine kinase activity.

The amino acid sequence deduced from cDNA of the single polypeptide chain precursor of human placental insulin receptor revealed that $\alpha$ - and $\beta$-subunits consist of 735 and 620 residues, respectively. The $\alpha$-subunit is hydrophilic, disulphide-bonded, glycosylated and probably extracellular. The $\beta$-subunit consists of a short extracellular region which links the $\alpha$-subunit through disulphide bridges, a hydrophobic transmembrane region and a longer cytoplasmic region which is structurally homologous with other tyrosine kinases like the src oncogene product and EGF receptor kinases.

The cellular function of insulin receptors is dual: transmembrane signalling and endocytosis of hormone. The binding of insulin to its receptor on the cell membrane induces transfer of signal from extracellular to cytoplasmic receptor domains leading to activation of cell metabolism and growth. In addition, hormone-receptor complexes are internalized leading to intracellular proteolysis of insulin, whereas receptors are recycled to the membrane. These phenomena are kinetically wellcharacterized, but their molecular mechanisms remain obscure.

Insulin receptor in different tissues and animal species are homologous in their structure and function, but show also significant differences regarding size of $\alpha$-subunits, binding kinetics, insulin specificity and receptor-mediated degradation. We suggest that this heterogeneity of receptors may be linked to the diversity in insulin effects on metabolism and growth in various cell types.

The purified insulin receptor phosphorylates its own $\beta$-subunit and exogenous protein and peptide substrates on tyrosine residues, a reaction which is insulin-sensitive, $\mathrm{Mn}^{2+}$-dependent and specific for ATP. Tyrosine phosphorylation of the $\beta$-subunit activates receptor kinase activity, and dephosphorylation with alkaline phosphatase deactivates the kinase. In intact cells or impure 

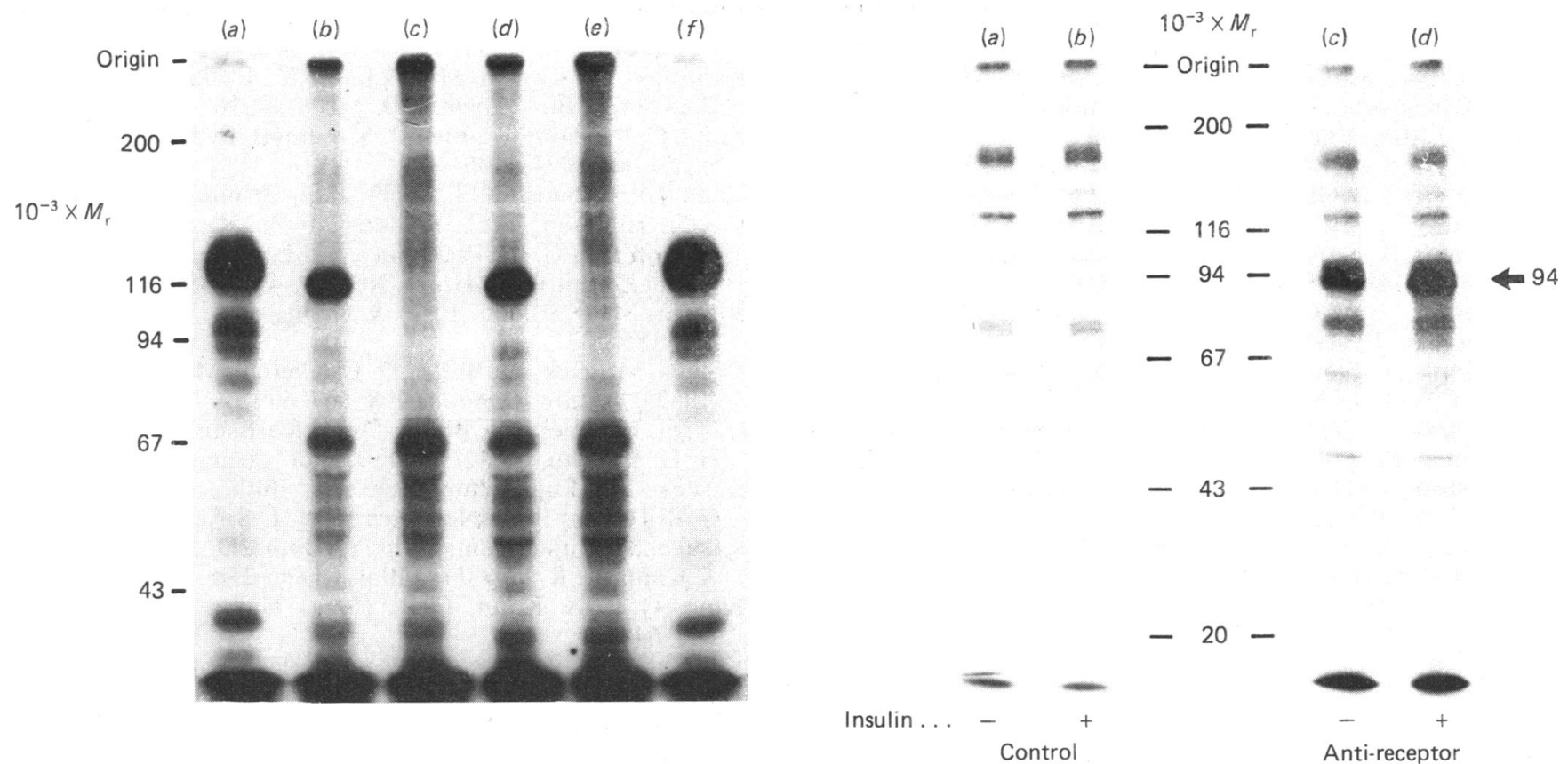

Fig. 5. Subunit structure of insulin receptors from rat brain cortex

Left panel: receptors on rat brain cortical plasma membranes $(b-e)$ were affinity labelled with photosensitive ${ }^{125} \mathrm{I}-$ insulin in absence $\left(b\right.$ and $d$ ) or presence of $10^{-6} \mathrm{M}$ unlabelled insulin ( $c$ and $e$ ). The radioactive proteins were analysed SDS/polyacrylamide-gel electrophoresis followed by autoradiography. Photoaffinity labelled receptors from rat liver are included on the gel for comparison ( $a$ and $f$ ). The mobility of specifically labelled brain insulin receptor $\alpha$-subunits $(b$ and $d)$ is significantly less than that of hepatic receptor $\alpha$-subunits $\left(M_{\mathrm{r}} \sim 115000\right.$ versus 130000). Right panel: partially purified receptors from rat brain cortex were phosphorylated with $\left[\gamma^{-32} \mathrm{P}\right] \mathrm{ATP}$ in the absence $(a$ and $c)$ or presence $(b$ and $d)$ of insulin $(0.1 \mu \mathrm{M})$, immunoprecipitated with antiserum to insulin receptor $(c$ and $d)$ or normal serum $(a$ and $b)$, and analysed by gel electrophoresis and autoradiography. The mobility of brain insulin receptor $\beta$-subunits $\left(M_{\mathrm{r}} \sim 94000\right)$ is identical with that of liver receptor $\beta$-subunits (cf. Fig. 3) (data from Gammeltoft et al., 1984a, 1985a).

receptor preparations, a serine kinase is also activated by insulin. The cellular role of two kinase activities associated with the insulin receptor is not known, but we propose that the tyrosine- and serine-specific kinases mediate insulin actions on metabolism and growth either through dual-signalling or sequential pathways. A cellular glycoprotein $\left(M_{\mathrm{r}} \sim 110000\right)$, the phosphorylation of which is stimulated by insulin, may represent a physiological substrate of the receptor-associated kinases and an intermediary step in insulin action. Several arguments are in favor of this model: the identical insulin dose-response relationships of receptor binding, kinase activation and substrate phosphorylation; the insulin specificity of receptor kinase activation; the invariable association between binding and kinase activities of insulin receptors; and the impairment of receptor kinase activity in various insulin-resistant states.

B. Lieblein is thanked for typing the manuscript, the European Molecular Biology Organisation and the Institut National de la Santé et de la Recherche Médicale are thanked for supporting S. G. during a short-term fellowship in INSERM U 145, Nice, France.

\section{References}

Avruch, J., Nemenoff, R. A., Blackshear, P. J., Pierce, M. N. \& Osathanondh, R. (1982) J. Biol. Chem. 257, 15162-15166 Beck-Nielsen, H. \& Pedersen, O. (1979) Diabetologia 17, 77-84
Bergeron, J. J. M., Cruz, J., Khan, M. M. \& Posner, B. I. (1985) Annu. Rev. Physiol. 47, 383-403

Bishop, J. M. (1983) Annu. Rev. Biochem. 52, 301-354

Blackshear, P. J., Nemenoff, R. A. \& Avruch, J. (1983) FEBS Lett. 158, 243-246

Blackshear, P. J., Nemenoff, R. A. \& Avruch, J. (1984) Endocrinology (Baltimore) 114, 141-152

Burant, C. F., Treutelaar, M. K., Landreth, G. E. \& Buse, M. G. (1984) Diabetes 33, 704-708

Carpenter, G., King, L., Jr. \& Cohen, S. (1979) J. Biol. Chem. 254, 4884-4891

Carpentier, J.-L., Gorden, P., Freychet, P., Le Cam, A. \& Orci, L. (1979) J. Clin. Invest. 63, 1249-1261

Cheng, K. \& Larner, J. (1985) Annu. Rev. Physiol. 47, 405-424

Cohen, P. (1982) Nature (London) 296, 613-620

Cohen, S., Carpenter, G. \& King, L., Jr. (1980) J. Biol. Chem. 255, 4834-4842

Cuatrecasas, P. (1972) J. Biol. Chem. 247, 1980-1991

Czech, M. P. (1984) Recent Prog. Horm. Res. 40, 347-377

de Meyts, P., Bianco, A. R. \& Roth, J. (1976) J. Biol. Chem. 251, 1877-1888

Denton, R. M., Brownsey, R. M. \& Belsham, G. J. (1981) Diabetologia 21, 347-362

Donner, D. B. \& Corin, R. E. (1980) J. Biol. Chem. 255, 9005-9008

Downward, J., Yarden, Y., Mayes, E., Scrace, G., Totty, N., Stockwell, P., Ullrich, A., Schlessinger, J. \& Waterfield, M. D. (1984) Nature (London) 307, 521-524

Ebina, Y., Ellis, L., Jarnagin, K., Edery, M., Graf, L., Clauser, E., Jing-Hsiung, O., Masiarz, F., Kan, Y. W., Goldfine, I. D., Roth, R. A. \& Rutter, W. J.(1985) Cell 40, 747-758

Ek, B., Westermark, B., Wasteson, A. \& Heldin, C. K. (1982) Nature (London) 295, 419-421 
Fehlmann, M., Carpentier, J.-L., Van Obberghen, E., Freychet, P., Thamm, P., Saunders, D., Brandenburg, D. \& Orci, L. (1982) Proc. Natl. Acad. Sci. U.S.A. 79, 5921-5925

Fujita-Yamaguchi, Y., Choi, S., Sakamoto, Y. \& Itakura, K. (1983) J. Biol. Chem. 258, 5045-5049

Gammeltoft, S. (1984) Physiol. Rev. 64, 1321-1378

Gammeltoft, S. \& Gliemann, J. (1973) Biochim. Biophys. Acta 320, 16-32

Gammeltoft, S., Kristensen, L. Ø. \& Sestoft, L. (1978) J. Biol. Chem. 253, 8496-8413

Gammeltoft, S., Kowalski, A., Fehlmann, M. \& Van Obberghen, E. (1984a) FEBS Lett. 172, 87-90

Gammeltoft, S., Staun-Olsen, P., Ottesen, B. \& Fahrenkrug, J. (1984b) Peptides 5, 937-944

Gammeltoft, S., Fehlmann, M. \& Van Obberghen, E. (1985a) Biochimie 67, 1147-1153

Gammeltoft, S., Haselbacher, G., Humbel, R. E., Fehlmann, M. \& Van Obberghen, E. (1985b) EMBO J. 4, 3407-3412

Gazzano, H., Kowalski, A., Fehlmann, M. \& Van Obberghen, E. (1983) Biochem. J. 216, 575-582

Gazzano, H., Halban, P., Prentki, M., Ballotti, R., Brandenburg, D., Fehlmann, M. \& Van Obberghen, E. (1985) Biochem. J. 226, 867-872

Gliemann, J. \& Sonne, O. (1978) J. Biol. Chem. 253, 7857-7863

Gliemann, J., Gammeltoft, S. \& Vinten, J. (1975) J. Biol. Chem. 250, 3368-3374

Gorden, P., Carpentier, J. L., Freychet, P. \& Orci, L. (1980) Diabetologia 18, 263-274

Grigorescu, F., Flier, J. S. \& Kahn, C. R. (1984) J. Biol. Chem. 259, 15003-15006

Grigorescu, F., White, M. F. \& Kahn, C. R. (1983) J. Biol. Chem. 258, 13708-13716

Grunberger, G., Comi, R. J., Taylor, S. I. \& Gorden, P. (1984a) J. Clin. Endocrinol. Metab. 59, 1152-1158

Grunberger, G., Zick, Y. \& Gorden, P. (1984b) Science 223 , 932-934

Häring, H. U., Kasuga, M. \& Kahn, C. R. (1982) Biochem. Biophys. Res. Commun. 108, 1538-1545

Häring, H. U., Kasuga, M., White, M. F., Crettaz, M. \& Kahn, C. R. (1984a) Biochemistry 23, 3298-3306

Häring, H. U., Machicao, F., Kirsch, D., Rinninger, F., Hölzl, J., Eckel, J. \& Bachmann, W. (1984b) FEBS Lett. 176, 229-234

Häring, H. U., White, M. F., Kahn, C. R., Kasuga, M., Lauris, W., Fleischmann, R., Murray, M. \& Pawelek, J. (1984c) J. Cell. Biol. 99, 900-908

Harrison, L. C., Billington, T., East, I. J., Nichols, R. J. \& Clark, S. (1978) Endocrinology (Baltimore) 102, 1485-1495

Haselbacher, G., Schwab, M. E., Pasi, A. \& Humbel, R. E. (1985) Proc. Natl. Acad. Sci. U.S.A. 82, 2153-2157

Havrankova, J., Roth, J. \& Brownstein, M. (1978) Nature (London) 272, 827-829

Hedo, J. A., Kasuga, M., Van Obberghen, E., Roth, J. \& Kahn, C. R. (1981) Proc. Natl. Acad. Sci. U.S.A. 78, 4791-4795

Heidenreich, K. A., Zahnisser, N. R., Berhanu, P., Brandenburg, D. \& Olefsky, J. M. (1983) J. Biol. Chem. 258, 8527-8530

Heldin, C. H. \& Westermark, B. (1984) Cell 37, 9-20

Hendricks, S. A., Roth, J., Rishi, S., \& Becker, K. L. (1983) in Brain Peptides (Krieger, D. T., Brownstein, M. J. \& Martin, J. B., eds.), pp. 903-939, John Wiley and Sons, New York

Houslay, M. D. (1981) Biosci. Rep. 1, 19-38

Houslay, M. D. \& Heyworth, C. M. (1983) Trends Biochem. Sci. 8, 449-452

Hunter, T. (1982) J. Biol. Chem. 257, 4843-4848

Hunter, T. (1984) Sci. Amer. 251, 60-69

Hunter, T. \& Sefton, B. M. (1980) Proc. Natl. Acad. Sci. U.S.A. 77, 1311-1315

Jacobs, S. \& Cuatrecasas, P. (1981) Endocr. Rev. 2, 251-263

Jacobs, S., Schechter, Y., Bisell, K. \& Cuatrecasas, P. (1977) Biochem. Biophys. Res. Commun. 77, 981-988

Jacobs, S., Hazum, E., Schechter, Y. \& Cuatrecasas, P. (1979) Proc. Natl. Acad. Sci. U.S.A. 76, 4918-4921
Jacobs, S., Kull, F. C., Svoboda, M. E., Van Wyk, J. J. \& Cuatrecasas, P. (1983) J. Biol. Chem. 258, 9581-9584

Kadowaki, T., Kasuga, M., Akanum, Y., Ezaki, D. \& Takuku, F. (1984) J. Biol. Chem. 259, 14208-14216

Kahn, C. R., Baird, K., Flier, J. S. \& Jarett, D. B. (1977) J. Clin. Invest. 60, 1094-1106

Kahn, C. R., Baird, K. L., Flier, J. S., Grunfeld, C., Harmon, J. T., Harrison, L. C., Karlsson, F. A., Kasuga, M., King, G. L., Lang, U. C., Podskalny, F. M. \& Van Obberghen, E. (1981) Recent Prog. Horm. Res. 37, 477-538

Kasuga, M., Karlsson, F. A. \& Kahn, C. R. (1982a) Science 215, 185-187

Kasuga, M., Zick, Y., Blithe, D. L., Crettaz, M. \& Kahn, C. R. (1982b) Nature (London) 298, 667-669

Kasuga, M., Zick, Y., Blithe, D. L., Karlsson, F. A., Häring, H. U. \& Kahn, C. R. (1982c) J. Biol. Chem. 257, 9891-9894

Kasuga, M., Fujita-Yamaguchi, Y., Blithe, D. L. \& Kahn, C. R. (1983a) Proc. Natl. Acad. Sci. U.S.A. 80, 2137-2141

Kasuga, M., Fujita-Yamaguchi, Y., Blithe, D. L., White, M. F. \& Kahn, C. R. (1983b) J. Biol. Chem. 258, 10973-10980

King, G. L. \& Kahn, C. R. (1981) Nature (London) 292, 644-646

Kono, T. \& Barham, F. W. (1971) J. Biol. Chem. 246, 6210-6216

Kowalski, A., Gazzano, H., Fehlmann, M. \& Van Obberghen, E. (1983) Biochem. Biophys. Res. Commun. 117, 885-893

Kull, F. C., Jr., Jacobs, S., Su, Y.-F. Svoboda, M. E., Van Wyk, J. J. \& Cuatrecasas, P. (1983) J. Biol. Chem. 258, 6561-6566

Le Marchand-Brustel, Y., Grémeaux, T., Ballotti, R. \& Van Obberghen, E. (1985) Nature (London) 315, 676-679

Marsh, J. W., Westley, J. \& Steiner, D. F. (1984) J. Biol. Chem. 259, 6641-6649

Massagué, J., Pilch, P. F. \& Czech, M. P. (1981) J. Biol. Chem. 256, 3182-3190

Nemenoff, R. A., Kwok, Y. C., Shulman, G. I., Blackshear, P. J., Osathanondh, R. \& Avruch, J. (1984) J. Biol. Chem. 259, 5058-5065

Nickameyer, W. S. \& Wang, L. H. (1985) J. Virol. 53, 879-884

Pang, D. T. \& Schafer, J. A. (1984) J. Biol. Chem. 259, 8589-8596

Pang, D. T., Sharma, B. R., Schafer, J. A., White, M. F. \& Kahn, C. R. (1985) J. Biol. Chem. 260, 7131-7136

Pedersen, O., Hjøllund, E., Beck-Nielsen, H., Lindskov, H. O., Sonne, O. \& Gliemann, J. (1981) Diabetologia 20, 636-641

Petruzzelli, L. M., Ganguly, S., Smith, C. J., Cobb, M. H., Rubin, C. S. \& Rosen, O. M. (1982) Proc. Natl. Acad. Sci. U.S.A. 79, 6792-6796

Petruzzelli, L., Herrera, R. \& Rosen, O. M. (1984) Proc. Natl. Acad. Sci. U.S.A. 81, 3327-3331

Pilch, P. F. \& Czech, M. P. (1979) J. Biol. Chem. 254, 3375-3381

Pike, L. J., Kuenzel, E. A., Casnellie, J. E. \& Krebs, E. G. (1984) J. Biol. Chem. 259, 9913-9921

Pottick, L. A., Moxley, R. T., III \& Livingston, J. N. (1981) Diabetologia 30, 196-202

Rees-Jones, R. W. \& Taylor, S. I. (1985) J. Biol. Chem. 260, 4461-4467

Rees-Jones, R. W., Hedo, J. A., Zick, Y. \& Roth, J. (1983) Biochem. Biophys. Res. Commun. 116, 417-422

Rees-Jones, R. W., Hendricks, S. A., Quarum, M. \& Roth, J. (1984) J. Biol. Chem. 259, 3470-3474

Reynolds F. H., Jr., Todaro, G. J., Fryling, C. \& Stephenson, J. R. (1981) Nature (London) 292, 259-262

Rosen, O. M., Herrera, R., Olowe, Y., Petruzzelli, L. M. \& Cobb, M. H. (1983) Proc. Natl. Acad. Sci. U.S.A. 80, $3237-3240$

Roth, R. A. \& Cassell, D. J. (1983) Science 219, 299-301

Roth, R. A., Cassell, D. J., Wrong, K. Y., Maddux, B. A. \& Goldfine, I. D. (1982) Proc. Natl. Acad. Sci. U.S.A. 79, 7312-7316

Roth, R. A., Cassell, D. J., Maddux, D. A. \& Goldfine, I. D. (1983a) Biochem. Biophys. Res. Commun. 115, 245-252 
Roth, R. A., Mesirow, M. L. \& Cassell, D. J. (1983b) J. Biol. Chem. 258, 14456-14460

Roth, R. A., Cassell, D. J., Morgan, D. D., Tatnell, M. A., Jones, R. H., Schuttler, A. \& Brandenburg, D. (1984) FEBS Lett. 70, 360-364

Rubin, J. B., Shia, M. A. \& Pilch, P. F. (1983) Nature (London) 305, 438-440

Sadoul, J. L., Peyron, J. F., Ballotti, R., Debant, A., Fehlmann, M. \& Van Obberghen, E. (1985) Biochem. J. 227, 887-892

Shia, M. A. \& Pilch, P. F. (1983) Biochemistry 22, 717-721

Shia, M. A., Rubin, J. D. \& Pilch, P. F. (1983) J. Biol. Chem. 258, 14450-14455

Siegel, T. W., Ganguly, S., Jacobs, S., Rosen, D. M. \& Cuatrecasas, P. (1981) J. Biol. Chem. 256, 9266-9273

Simpson, I. A. \& Hedo, J. A. (1984) Science 223, 1301-1304

Sonne, O. \& Gliemann, J. (1980) J. Biol. Chem. 255, 74497454

Stadtmauer, L. A. \& Rosen, D. W. (1983) J. Biol. Chem. 258, 6682-6685

Suzuki, K. \& Kono, T. (1979) J. Biol. Chem. 254, 9786-9794

Tamura, S., Brown, T. A., Dubler, R. E. \& Larner, J. (1983a) Biochem. Biophys. Res. Commun. 113, 80-86

Tamura, S., Fujita-Yamaguchi, Y. \& Larner, J. (1983b) J. Biol. Chem. 258, 14749-14752

Terris, S. \& Steiner, D. F. (1975) J. Biol. Chem. 250, 83898398

Ullrich, A., Bell, J. R., Chen, E. Y., Herrera, R., Petruzzelli, L. M., Dull, T. J., Gray, A., Coussens, L., Liao, Y.-C., Tsubokawa, M., Mason, A., Seeburg, P. H., Grunfeld, C., Rosen, O. M. \& Ramachandran, J. (1985) Nature (London) 313, 756-761

Ullrich, A., Coussens, L., Hayflick, J. S., Dull, T. J., Gray, A., Tam, A. W., Lee, J., Yarden, Y., Libermann, T. A., Schlessinger, J., Downward, J., Mayes, E. L. V., Whittle, N., Waterfield, M. D. \& Seeburg, P. H. (1984) Nature (London) 309, 418-425

Van Obberghen, E. (1984) Biochem. Pharmacol. 33, 889-896
Van Obberghen, E. \& Kowalski, A. (1982) FEBS Lett. 143, 179-182

Van Obberghen, E., Kasuga, M., Le Cam, A., Hedo, J. A., Itin, A. \& Harrison, L. C. (1981) Proc. Natl. Acad. Sci. U.S.A. 78, 1052-1056

Van Obberghen, E., Rossi, B., Kowalski, A., Gazzano, H. \& Ponzio, G. (1983) Proc. Natl. Acad. Sci. U.S.A. 80, 945-949

Van Obberghen, E., Ballotti, R., Gazzano, H., Fehlmann, M., Rossi, B., Gammeltoft, S., Debant, A., Le Marchand-Brustel, Y. \& Kowalski, A. (1985) Biochimie 67, 1119-1123

Van Schravendijk, C. F. H., Hooghe-Peters, E. L., De Meyts, P. \& Pipeleers, D. G. (1984) Biochem. J. 220, 165-172

Velicelebi, G. \& Aiyer, R. A. (1984) Proc. Natl. Acad. Sci. U.S.A. 81, 7693-7697

White, M. F., Häring, H. U., Kasuga, M. \& Kahn, C. R. (1984) J. Biol. Chem. 259, 255-264

White, M. F., Takayama, S. \& Kahn, C. R. (1985) J. Biol. Chem. 260, 9470-9478

Yamamoto, T., Davis, C. G., Brown, M. S., Schneider, W. J., Casey, M. L., Goldstein, J. L. \& Russell, D. W. (1984) Cell 39, 27-38

Yip, C. C., Yeung, C. W. T. \& Moule, M. L. (1978) J. Biol. Chem. 253, 1743-1745

Yip, C. C., Moule, M. L. \& Yeung, W. T. (1980) Biochem. Biophys. Res. Commun. 96, 1671-1678

Yu, K. T. \& Czech, M. P. (1984) J. Biol. Chem. 259, 5277-5286

Yu, K. T., Werth, D. K., Pastan, I. H. \& Czech, M. P. (1985) J. Biol. Chem. 260, 5838-5846

Zick, Y., Grunberger, G., Podskalny, J. M., Moncada, V., Taylor, S. I., Gorden, P. \& Roth, J. (1983a) Biochem. Biophys. Res. Commun. 116, 1129-1135

Zick, Y., Kasuga, M., Kahn, C. R. \& Roth, J. (1983b) J. Biol. Chem. 258, 75-80

Zick, Y., Whittaker, J. \& Roth, J. (1983c) J. Biol. Chem. 258, 3431-3434

Zick, Y., Rees-Jones, R. W., Taylor, S. I., Gorden, P. \& Roth, J. (1984) J. Biol. Chem. 259, 4396-4400 